persons oversubscribing to attempted suicide rates. This, again, may be partly due to the suicidogenic potential of schizophrenia, alcoholism, and psychopathy -as may their possibly increased rates of violent crime both within and without the Irish setting. Certainly, violent deaths seem commoner among Irishborn immigrants. ${ }^{16}$ It is noteworthy that Roman Catholic priests working in Englandwho presumably are more likely to be of Irish extraction-have a higher mortality than Anglican clergy. ${ }^{17}$

Most of the conditions mentioned have strong genetic determinants. For instance, the tissue histocompatibility antigen HLA-B8, which is relatively frequent in Irish populations, ${ }^{1}$ has been found increased in alcoholic cirrhosis ${ }^{18}$ and gluten enteropathy. ${ }^{119}$

One might speculate that, while the breaking up of small population isolates may be a dilution effect to reduce disease incidence-for example, in Sweden, resulting in a decline in Tay-Sachs disease $\mathrm{2}^{20}$-so, conversely, the influx of "high-risk" gene pool individuals may raise the disease rates in the localities in which they settle. This hypothesis could be tested in the UK by analysing regional differences in schizophrenia or alcoholism rates and comparing these with regional differences in immigrant ratios. This genetic argument, which is often-as in your leading articlenot at all considered, may hold the key to many epidemiological puzzles.

Botleys Park Hospital,

Herbert G KinNell

Botleys Park Hosp
Chertsey, Surrey

Oliver RTD. Br $\mathcal{O}$ Hosp Med 1977;449-459.

The Medical Research Council Steering Committe for the MRC/DHSS Phenylketonuria Register. Br Med F 1981;282:1680-5.

Elu ood JH, Nevin NC. Ulster Med f 1973;42:213.

- MacKay DN, McDonald G. Lancet 1974;1173.

McNamara J. Bilingualism and primary education. 1966, Edinburgh.

Eysenck HJ. Race, intelligence and education. London Temple Smith, 1971:127.

' Walsh D, et al. Psychol Med 1980;10:465-70. Kelleher MJ, Copeland JRM, Smith AJ. Psychol Med $1974 ; 4: 460-2$.

'Krupinski J, Stoller A. Med F Aust 1965 ;ii :265-9.

Clare AW. A study of psychiatric illness in an immigrant Irish population. MPhil thesis, University of London, 1972.

282.1831-3 282:1831-3.

12 Griffiths DLL. Br f Hosp Med 1975;14:146.

14 Anonymous. Br Med $\mathcal{F} 1978$;ii:1107. ean G, MacLennan

Br f Cancer 1979;40:581-9.
Burke AW. Br F Psych 1976;128:534-7.

is Burvill PW, McCall MG, Stenhouse NS, Reid TA. Acta Psych Scand 1973;49:28-50.

12 Registrar General. Decennial supplement for England and Wales 1951: occupational mortality. London HMSO, 1958.

${ }^{18}$ Eddleston ALWF, Williams R. Br Med Bull 1978 34:299.

19 Vicary FR. Hospital Update 1979;5:725-9.

${ }^{\circ}$ Rayner S. Hereditas 1964;51:297.

\section{Management of alcohol withdrawal symptoms}

SIR,-The leading article (14 February, p 502) on the management of the alcoholic withdrawa syndrome ignores some of the most recent work showing that the opiate system in man is probably involved in both alcohol and opiate addiction. ${ }^{2}$

Based on this work and the fact that there is cross-tolerance between alcohol and nitrous oxide, $^{3}$ we have suggested ${ }^{4}$ that nitrous oxide may be useful in treating both alcoholic and opiate withdrawal states, as nitrous oxide acts as an agonist on the opiate system. ${ }^{5}$ This hypothesis has been tested to date on over 300 cases at Northlea Hospital (an alcoholic rehabilitation centre near Johannesburg) using a modified version of the clinical criteria shown by Gross et al to be useful in the assessment of alcoholic withdrawal states. ${ }^{6}$

We found also (as had van Wulfften Palthe ${ }^{7}$ ) that oxygen alone had a therapeutic effect, which was further enhanced by the use of analgesic mixtures of nitrous oxide and oxygen when necessary. This treatment has proved so successful in both patient compliance and reduction of sedation necessary that it is now regarded as the routine therapy at Northlea.

\section{A Gillman F J LICHTIGFELD}

Department of Experimental and

Clinical Pharmacology,

University of Witwatersrand

Johannesburg 1 Blum K, Hamilton MG, Wallace JE. In: Blum K, ed.
Alcohol and opiates. New York: Academic Press, 1977:203-36.

2 Eskelson CD, Hameroff SR, Kanel JS. Anesthesia and Analgesia 1980;59:537-8.

Koblin DD, Deady JE, Dong DE, et al. F Pharmacol Exp Ther 1980;213:309-12.

- Gillman MA, Lichtigfeld FJ. Lancet 1980;ii :803.

Gillman MA, Kok L, Lichtigfeld FJ. Europ $\mathcal{Y}$ Pharma col 1980;2:175-7.

Gross MM, Lewis E, Nagarajan M. Adv Exp Med
Biol 1973;35:365-77. Biol 1973;35:365-77. van Wulften Palthe PM. Deutsche Zeitschrift für

\section{Pneumoconiosis and disability}

SIR,-I was interested to read in Dr George Dunea's "Letter from Chicago" (30 May, p 1773) his report of a study by the General Accounting Office which had found that $88 \%$ of claimants approved for pneumoconiosis benefits were found to be neither disabled nor able to produce a medical certificate.

In 1976 a group of 14 North Staffordshire general practitioners took part in a study of the disabling effects-physical and social-of pneumoconiosis on patients on their list, and data were collected over a three-year period. A report on this study is still in preparation. The subject of the study was chosen because the doctors were aware of apparent discrepancies between patients' lung disabilities and their pneumoconiosis pension. Ninetynine patients were interviewed using one questionnaire (approved by the Medical Research Council) which attempted to measure their respiratory symptoms. A second questionnaire tried to identify any social disability due to the patient's pneumoconiosis. No significant relationship was identified between disability and pneumoconiosis pension.

The difficulties of assessing disability are well known. We had no control group-the problems involved were considered too great for our small study. We were also unable to obtain information from the Department of Health and Social Security on the incidence or prevalence of pneumoconiosis in the Stoke-on-Trent area. Therefore, we could not claim that our sample was representative$84 \%$ of our patients had simple pneumoconiosis, which has doubtful disabling effects.

Our study therefore did not answer any questions but rather tended to raise some. One of the more surprising facts we did find was that more than half the study group, all in receipt of a pneumoconiosis pension, had never had a lung function test carried out.

As general practitioners working in an area where miner's and potter's pneumoconiosis was prevalent in the past, and considerable lung damage was suffered by workers in those industries, we are delighted that pneu- moconiosis is now a diminishing problem, and we fully support the practice of compensation for those afflicted.

What our study has revealed to us, however, is that pneumoconiosis pensions would appear to be awarded on lung $x$-ray examination appearances rather than lung disability present, and this does not seem to be fully appreciated in the general medical profession or the general public.

A K Ross

University of Keele,

North Staffordshire Medica

Institute,

Stoke-on-Trent ST4 7NY

\section{Mixed-sex wards}

SIR,-I was greatly surprised to read in your leading article (30 May, p 1736) that mixed wards have given "overwhelming satisfaction" to "both staff and patients." Every report I have had from patients who have experienced them has been wholly adverse. Even the favoured type of mixed ward with single-sex bays and separate toilets did not protect a female friend from the catcalls from the neighbouring male bay every time she moved towards the toilets - a singularly inappropriate serenade for one coming to terms with the loss of a breast.

In January 1979 a brief letter was published in the Daily Telegraph suggesting that those who were against mixed wards (some of whose complaints had appeared in the correspondence columns of that newspaper) might care to express support for the survival of the singlesex Elizabeth Garrett Anderson Hospital. Over 300 letters were promptly received, all expressing distaste for the mixed ward, some citing very unpleasant experiences in them and some offering, or enclosing, unsolicited money -telling evidence of the strength of their feelings.

Also in 1979, the annual general meeting of the National Federation of Women's Institutes passed a resolution pressing for mixed wards to be discontinued (except for intensive care). This means that every one of the 9300 institutes up and down the country (representing some 400000 women) had discussed the subject with the aid of expert notes listing impartially the arguments for and against, and that at least two-thirds of the institutes had instructed their delegates to vote in favour of discontinuing mixed wards.

Could it be that once again starry-eyed planners have predetermined consumer wants? Strangely, your article does report some criticism of the mixing of sexes in the day areas, where I would have thought it acceptable, and suggests that "separate day areas" would reduce that criticism-a suggestion which seems to me to make nonsense of the whole argument.

Kenley, Surrey CR2 5DR

MARgaRet LOUDEN

\section{Assessing clinical trials}

SIR,-I read with enthusiasm the contribution by Sheila Gore, "Assessing clinical trialsfirst steps" (16 May, p 1605). Not only was she able to make all important points within a rather compact presentation but she also supplied one commonly omitted consideration: so-called "pilot" studies require randomisation.

It is scientifically appropriate to insist on randomisation of all patients receiving a new 